\title{
Rozwój semantyczny leksemu inspiracja
}

\author{
Ilona Koziarska*
}

Główne źródło wiedzy o historii i rozwoju słownictwa stanowią słowniki. W artykule analizie słownikowej poddany zostanie leksem inspiracja będący jednocześnie tytułem niniejszej publikacji. Obecnie za jego synonimy uznaje się m.in. rzeczowniki: wena, natchnienie, muza, a także wyrażenia zapał twórczy, czynnik mobilizujacy. Historia inspiracji w polszczyźnie, według dostępnych źródeł leksykograficznych, sięga XVII wieku. Jest to wyraz zapożyczony z języka łacińskiego - łac. inspiratio, czyli 'wdech, tchnienie, rozniecanie'.

Po przeniesieniu leksemu na grunt polszczyzny, co nastąpiło około XVII wieku, wyraz zapisywany był zgodnie z ówczesnymi normami ortograficznymi - inspiracyja, a objaśniany jako 'natchnienie', ale o silnych konotacjach teologicznych. Według Stownika jezyka polskiego Samuela Bogumiła Lindego inspirowany to inaczej natchniony ${ }^{1}$, a wtedy natchnienie odnosiło się do Pisma Świętego uznawanego za uduchowione - powstałe pod wpływem działania Ducha Świętego. Podobnie przedstawia charakterystykę tego leksemu tzw. słownik wileński ${ }^{2}$. Rozszerzenie znaczenia następuje na początku XX wieku, co odnotowuje Stownik jezyka polskiego, zwany potocznie słownikiem warszawskim. Przy haśle inspiracja pojawiają się dwa kwalifikatory: „1. (w estetyce) natchnienie, objawienie. 2. (w psychologii) poddawanie bez

* Uniwersytet Lódzki, Wydział Filologiczny, Instytut Filologii Polskiej i Logopedii, Pracownia Edytorstwa, 90-236 Łódź, ul. Pomorska 171/173, e-mail: ilona.koziarska@uni.lodz.eu.

1 S. B. Linde, Stownik jezyka polskiego, [hasło] Inspiracja, t. 2, Lwów 1855, s. 208.

2 Stownik.jezyka polskiego, red. M. Orgelbrand, [hasło] Inspiracja, t. 1, Wilno 1861, s. 421. 
pośrednictwa wzroku i słuchu przy odgadywaniu myśli”3. Oznacza to przeniesienie leksemu do innych dziedzin naukowych, takich jak psychologia czy mieszcząca się w obszarze filozofii estetyka.

W drugiej połowie XX wieku wyłaniają się następne znaczenia inspiracji: 'poddawanie myśli, namowa, wpływ wywierany na kogoś; sugestia'4 - określenia obecnie klasyfikowane jako synonimiczne względem perswazji, co Doroszewski zilustrował następującym przykładem: „Inspiracje Czartoryskiego sprawiły, że Kościuszko napisał list do Cesarza Aleksandra". Jak widać, zacytowane inspiracje dziś mogłyby zostać zastapione leksemami: wpływy, namowy, sugestie czy prz̨ekonywanie. Wszystkie te określenia mieszczą się w obrębie pola semantycznego leksemu perswazja. Na trzecim miejscu w wyżej wspomnianym słowniku pojawiło się wdychanie powietrza, czyli dosłowne nazwanie podstawowej czynności życiowej.

Współcześnie spośród wyżej wymienionych znaczeń rzeczownika inspiracja, kilka prezentuje Stownik wyrazón obcych pod redakcją Elżbiety Sobol wydany w 1995 roku. Zdefiniowano w nim inspiracje jako: „1. natchnienie, zapał twórczy. 2. wpływ wywierany na kogoś, 3. poddawanie myśli, sugestię" . Definicja ta zostaje uzupełniona przez kolejne nowe znaczenia obecne w internetowym Wielkim stowniku jezyka polskiego pod redakcją Piotra Żmigrodzkiego. Nadane zostaja dwie kwalifikacje tematyczne, z których każda jest szczegółowo omówiona. Pierwsza z nich to działalność artystycźna człowieka, w której mieści się inspiracja rozumiana jako 'natchnienie, zachęta do działania, zwłaszcza do pracy twórczej', dla której synonimem jest wena. W następujący sposób zaprezentowano użycie omawianego znaczenia leksemu na podstawie Narodowego Korpusu Języka Polskiego (NKJP):

Wrażliwość na sprawy społeczne jest ogromną inspiracja dla działań studentów [...].

(Źródło: NKJP: Agnieszka Rasmus-Zgorzelska, Misja prz̨edmiotu, „Ozon”, 2005)

3 Stownik jezylea polskiego, red. J. Karłowicz, A. A. Kryński, W. Niedźwiedzki, [hasło] Inspiracja, t. 2, Warszawa 1902, s. 98.

4 Stownik, jezyka polskiego, red. W. Doroszewski, [hasło] Inspiracja, https://sjp.pwn.pl/doroszewski/ inspiracja;5434889.html [dostęp: 25.06.2018].

5 Stownik wyrazón obcych, red. E. Sobol, [hasło] Inspiracja, Warszawa 1995, s. 477. 
Nie wiadomo, czy inspiracje dla inżynierów stanowiły japońskie kreskówki, w których motocykl zmienia się w samochód, a ten w samolot, ale to niemal pewne, że samoloty przyszłości będą zmieniać kształt.

(Źródło: KWSJP: Marcin Bójko, Samolot jak z gumy, 2005)

Podczas wczorajszej sesji opozycyjny [...] przewodniczący Rady Miasta [...] oświadczył, iż z inspiracji politycznej został zaatakowany przez media $[\ldots]$.

(Źródło: NKJP: Hak za hak, „,Dziennik Polski”, 1.06.2001)

Według Wielkiego stownika jezyka polskiego ${ }^{6}$ inspiracja odnosi się także do określania relacji międzyludzkich, bowiem jest to również wpływ wywierany na kogoś. Synonimicznie traktowana jako sugestia, co widać w następujących przykładach z NKJP:

W kijowskim biurze UNA milicja urządziła pokazowy pogrom [...] Szef UNA [...] trafił do więzienia nieprzytomny, z wstrząsem mózgu i śladami ciężkiego pobicia na całym ciele. Jeśli rzeczywiście wywołał burdy z inspiracji władz, słono za to zapłacił.

(Źródło: KWSJP: Marcin Wojciechowski, Pomarańczowy majdan, 2006)

Podczas gdy doradcy starają się rozwiązać kwadraturę koła w kwestii deficytu, kolejna inicjatywa Białego Domu wyszła z inspiracji pani Hillary Clinton. Najnowszy projekt przewiduje objęcie szczepieniami ochronnymi wszystkich dzieci w Ameryce.

(Źródło: NKJP: Jacek Kalabiński, Falstart prezydencki, „Gazeta Wyborcza”, 3.02.1993)

Na podstawie powyższej analizy można wysnuć wniosek, że semantyka wyrazu inspiracja nie uległa na przestrzeni wieków dużej zmianie. Nastapiło subtelne przesunięcie znaczenia $z$ dosłownego, mającego związek z czynnością życiowa, jaką jest oddychanie (wdech, tchnienie) do poziomu bardziej abstrakcyjnego - wyspecjalizowało się znaczenie opisujące relacje międzyludzkie oraz pracę twórczą. To ostatnie rozumienie jest szczególnie widoczne we wszechobecnych współcześnie mass mediach, w których omawiany leksem jest nadużywany. Dziś inspiracja jest ktoś, kto wcześniej

6 Wielki stownik,jezyka polskiego, red. P. Żmigrodzki, [hasło] Inspiracja, http://www.wsjp.pl/do_druku.php?id_hasla=10923\&id_znaczenia=0 [dostęp: 25.06.2018]. 
nazywany był autorytetem; może to być również wydarzenie, zjawisko, a nawet produkt w reklamach komercyjnych. Inspiracje docieraja do nas zewsząd i staja się coraz popularniejsze, poszerzając obecne granice semantyczne tej jednostki leksykalnej, co przedstawili Autorzy niniejszej monografii.

\section{Bibliografia}

Linde S. B., Stownik jezyka polskiego, [hasło] Inspiracja, t. 2, Lwów 1855, s. 208.

Stownik jezyka polskiego, red. M. Orgelbrand, [hasło] Inspiracja, t. 1, Wilno 1861, s. 421.

Stownik. jezyke polskiego, red. J. Karłowicz, A. A. Kryński, W. Niedźwiedzki, [hasło] Inspiracja, t. 2, Warszawa 1902, s. 98.

Stownik wyrazón obcych, red. E. Sobol, [hasło] Inspiracja, Warszawa 1995, s. 477.

\section{Netografia}

Stownik, jezyka polskiego, red. W. Doroszewski, [hasło] Inspiracja, https://sjp. pwn.pl/doroszewski/inspiracja;5434889.html [dostęp: 25.06.2018].

Wielki stownik jezyka polskiego, red. P. Żmigrodzki, [hasło] Inspiracja, http:// www.wsjp.pl/do_druku.php?id_hasla=10923\&id_znaczenia=0 [dostęp: 25.06.2018]. 